\title{
Ceilândia, Cidade em Flor e Quarto de Despejo: Diário de uma Favelada - constituição/desconstituição do sujeito no espaço urbano
}

\author{
Eloísa Pereira Barroso* \\ Maria Helenice Barroso**
}

\begin{abstract}
RESUMO
O uso da literatura, neste artigo, explicita a relação entre arte e história, posto que a mesma pode se constituir em um lugar cuja produção possibilita a inserção do pensamento histórico. Desta maneira, a arte literária tomada como construtora de imagens do mundo social possibilita reflexões históricas acerca da cidade sob diferentes olhares. Com o auxílio do instrumental teóricometodológico da história, Ceilândia, Cidade em Flor (Manoel Raimundo) e Quarto de Despejo: Diário de Uma Favelada (Carolina Maria de Jesus) serão estudados na perspectiva da literatura e considerados "fonte de inspiração" para a poética da produção do conhecimento historiográfico.
\end{abstract}

Palavras-chave: História. Literatura. Cidade.

\section{Ceilândia, City in Flower and Dumping Room: Diary of a Slum - constitution/desconstitution of the subject in the urban space}

\begin{abstract}
The use of literature in this paper makes explicit the relation between art and history, since it can be constituted in a place whose production enables the insertion on the historical thought. In this way, the literary art taken as a constructor of social world images enables historical observations about the city under different views. With the aid of the theoretical-methodological instruments of history, Ceilândia, Cidade em Flor (Manoel Raimundo) and Quarto de Despejo: Diário de Uma Favelada (Carolina Maria de Jesus) will be studied in the perspective of literature and considered "inspiration source" for the poetic of the production of historiographic knowledge.
\end{abstract}

Keywords: History. Literature. City.

Artigo recebido em 16 jan. 2019

Aprovado em 3 jun. 2019

\footnotetext{
* Graduada em Letras pela Universidade de Brasília (1997), mestre em Sociologia pela Universidade de Brasília (2004), doutora em Sociologia pela Universidade de Brasília (2008). Professora adjunta da Universidade de Brasília do Departamento de História e cadastrada ao programa de Mestrado Profissional em Turismo do CET/ UnB e ao Programa de Pós-Graduação em História da UnB. E-mail: eloisabarroso@unb.br.

${ }^{* *}$ Doutora em História Cultural pela Universidade de Brasília-UnB (2013), com estágio na Universidade Nova de Lisboa. Mestre em História Cultural pela UnB (2006) e graduação em História pelo Centro Universitário de Brasília (1986). Membro do Grupo de Estudos Imaginário. Integrante do Laboratório de História Oral e Memória da UnB. E-mail: helebarroso@gmail.com.
} 
Conforme Terry Eagleton em seu livro Teoria da literatura: uma introdução, não há nenhuma 'teoria literária' no sentido de um corpo teórico que se origine da literatura, ou seja, exclusivamente aplicável a ela (Eagleton, 2001). Isto equivale dizer que todas as abordagens da crítica literária apresentadas no referido livro não dizem respeito apenas à escrita 'literária'. Pelo contrário, todas elas provêm de outras áreas das humanidades, e têm implicações que em muito se extrapolam a própria literatura.

Seguindo a esteira dessa afirmação, o que se pretende neste artigo é estabelecer um diálogo entre a Literatura e a História. Procurar-se-á aqui, a partir da leitura e interpretação do cordel Ceilândia, cidade em flor - de Manoel Raimundo, produzido em Ceilândia, sobre Ceilândia - e também com base na análise do livro Quarto de despejo: diário de uma favelada - escrito por Carolina Maria de Jesus, referente à favela do Canindé, em São Paulo - a possibilidade de entender como se estabelece a apropriação do espaço urbano e a construção de sua "atmosfera"; enfim, como se engendra a sociabilidade e como são construídas as identidades dos diversos atores sociais nesta ambiência.

Tanto no livro de Carolina Maria de Jesus quanto no cordel de Manoel Raimundo, o mundo urbano não pode ser visto como homogêneo, mas composto de variados microcosmos sociais ou subgrupos construídos no fazer cotidiano, tanto daqueles que detêm o capital econômico como também de homens e mulheres comuns.

Faz parte da proposta desse artigo, além de estabelecer a conexão entre as várias leituras - da obra de Carolina Maria de Jesus, de Manoel Raimundo, de teóricos literários, de sociólogos e de historiadores - situar as diferentes criações literárias, consideradas, canônicas ou não, como sendo parte de um processo de construção artística, mas que também podem ser consideradas como importantes vestígios históricos, os quais permitem múltiplas leituras do mundo.

Através do entrecruzamento desses variados discursos, o processo de construção epistemológica da História pode assumir um caráter de discurso polifônico que possibilitará uma interface ampliada entre os distintos campos de construção de saberes científicos e de criação artística.

Entretanto, não se pretende esgotar aqui tema tão vasto, mesmo por que existirá, em se tratando da perspectiva de construção epistemológica centrada nos paradigmas da nova história, uma sensibilidade outra, a "sensibilidade barroca"1.

A história, assim como as ciências sociais em geral, ancorada nos pressupostos da racionalidade, de grandes heróis e do tempo linear, enaltecidos pela modernidade, sofre transformações metodológicas de grande relevância, a partir das discussões realizadas pelos historiadores da Escola dos Annales, bem como dos historiadores ingleses, entre outros. 
Essa afirmação de uma nova postura em relação à pesquisa histórica apresenta implicações que levam à valorização do cotidiano, das "coisas miúdas da vida" do coletivo e também do individual. A epistème histórica passa a ser construída a partir da ênfase na necessidade de adoção de uma outra atitude para a análise do objeto de pesquisa; amplia-se o conceito de fonte para além do documento oficial escrito e legitimado por uma elite, seja de intelectuais, institucional ou econômica; outros lugares adquirem validade para a investigação do historiador.

La Nouvelle Histoire leva em consideração paradigmas outros, propostos pela nova geração de historiadores da história cultural, que segundo os ingleses são: a importância de levar em conta a subjetividade do pesquisador; pensar a 'realidade' como social ou culturalmente constituída; preocupação não apenas com a "história vista de cima" (Maffesoli, 1984), mas também com a "história vista de baixo" e a inter-relação entre elas; quebra com a hierarquização dos documentos oficiais escritos; preocupação com a análise das estruturas, entre outros.

À luz dessas discussões, a compreensão da complexa realidade social de uma nação, de uma cidade ou de qualquer outro grupo social, pode estar nos pequenos acontecimentos do cotidiano. Cotidiano esse refutado pelos positivistas e desprezado pela modernidade, que privilegiou os grandes feitos, as grandes civilizações. Que determinou padrões culturais e verdades universais, elegeu os grandes heróis da história, negou ao homem comum a sua diversidade, a beleza de sua despretensa historicidade e seu valor para o entendimento mais aprofundado de uma dada sociedade.

Esses novos paradigmas, trazidos a partir dos anos 1960 e 70, possibilitam às ciências sociais o entendimento dos habitus constitutivos dos vários campus ${ }^{2}$ de uma sociedade e permitem ao historiador uma análise aprofundada dos mais diversos aspectos da vida humana em uma determinada época (Bourdieu, 1999). Pode-se perceber que a nova história amplia o território do historiador, além de proporcionar uma postura interdisciplinar da produção historiográfica. A partir da Nova História, o campo da historiografia se abre para outras fontes históricas, reconhece a limitação do historiador em recriar o passado, e passa a buscar representações, símbolos que compunham o imaginário da época. Assim, o texto literário, discurso que traz informações $e$ sensibilidades acerca do passado, pode ser incorporado enquanto fonte de pesquisa.

Acreditanto nas possibilidades dessas novas fontes é que tomamos os textos literários aqui analisados para as reflexões acerca do espaço urbano no mundo moderno. Os textos literários em pauta permitem entrever o tecido constitutivo da modernidade; seja nos romances, seja nas crônicas, seja na poesia, ou no conto, a linguagem literária coloca em xeque as reflexões de um tempo e de um espaço. Os escritores, ao captarem a sensibilidade moderna, conseguem penetrar fundo no paradoxo do processo de modernização. O mundo social para estes autores não é apenas uma reflexão sobre a realidade política, mas é, também, um lugar de conteúdo e forma, onde as 
vozes dos sujeitos constroem e desconstroem a sociedade, e fazem emergir, por meio de múltiplos recursos linguísticos, representações outras da realidade.

Ao fixarem a realidade social em seus textos, os artistas procuram fomentar uma representação da realidade. A literatura não pode ser lida como algo que divorcia o homem de sua realidade social. Como uma forma de protesto contra a sociedade capitalista, ela se transforma cada vez mais. As interações estabelecidas no interior de uma sociedade são infinitamente complexas, pois as forças produtivas estão em transformações contínuas, portanto um conteúdo social jamais se expressa diretamente. Dessa maneira, uma pesquisa historiográfica que tem como fonte a literatura precisa estar atenta a esse caráter oblíquo colocado por ela. Assim, a seguinte questão se coloca: Como são combinados os elementos sociais e temáticos para a criação dessa narrativa?

A literatura transforma em algo novo o já existente. As novas maneiras elaboradas para se ver e ouvir estão intimamente ligadas às realidades sociais por ela configuradas. Essa perspectiva nos faz crer na relevância do elemento social para a constituição do texto literário. Isso pode fazer da obra de arte literária, também, uma forma solidificada de experiência social; porém, a essa solidez não deve estar imputada a ideia de paralisia, pois a produção material humana enriquece de experiência a expressão artística literária do homem.

A literatura é experiência humana, e como tal, mesmo no seu mais alto grau de subjetividade, não deixa de ser uma experiência social. Fischer vê o poeta como o descobridor da experiência; por meio dele, outros aprendem a reconhecê-la como experiência também deles e, por meio da expressão encontrada, chegam a assimilá-la (Fischer, 1983).

Assim, a configuração do espaço e do tempo é apresentada como algo dado pelo imaginário e pelas representações que se entrelaçam no cotidiano dos atores sociais. Por isso, esta pesquisa trabalha sobre o pressuposto de uma leitura do social, do econômico e do político que, ao mesmo tempo em que perpassa, é também perpassado pelo cultural. Isso permite sublinhar a pertinência da literatura para apontar lugares diferentes de inserção para a procedência de estudos históricos.

O contraponto entre ciência e arte alimenta-se de um debate antigo. Muitos alegam a existência do artístico na ciência e a presença científica na arte. A multiplicidade do diálogo é reiterada ao longo dos tempos. Às vezes esses diálogos se instauram de forma polifônica, outras fazem um uso instrumental da arte ou da ciência para ilustrar reflexões dos artistas ou dos cientistas.

Tanto a ciência quanto a arte possuem marcas próprias. É necessário especificar seus campos e realçar seus domínios. No contraponto entre história e literatura é importante reconhecer suas distinções, para então trabalharmos no sentido de criar análises do real em que as duas formas 
de linguagem se coloquem como possibilidades de conhecimento. A literatura $e$ a história juntas são capazes de decantar a realidade e produzir o encanto e o desencanto. Ao reconhecer o emaranhado de relações, as tensões e as contradições, a história decanta a realidade em conceitos e categorias. Ao juntar-se literatura e história na leitura do mundo social é possível a construção de tipologias para a compreensão da sociedade.

Fazer análise historiográfica via texto literário é entrar em um mundo de convergências e revelações. No caso específico dos autores selecionados, é possível contrapontos dialéticos entre modernidade e modernismo, racionalização e alienação, encanto e desencanto. Essas possibilidades se colocam como sínteses de uma sociedade paradoxal onde se tentou juntar desenvolvimento e esperança, duas coisas essenciais para a reatualização da dinâmica social.

A linguagem literária aponta para uma abordagem histórica que possibilita uma releitura da história ligada aos acontecimentos do cotidiano e da vida do homem e da mulher comum. Desse modo, ao considerar que a análise da produção literária de uma determinada época apresenta-se como de grande importância para o estudo da história dessa dada sociedade, vemos a literatura como fonte de pesquisa histórica de grande valor, na medida em que deixa entrever a possibilidade de incorporar à narrativa historiográfica as tensões sociais, os medos, os prazeres, as fantasias reveladas pelo escritor, pois como afirma Roland Barthes,

[...] a literatura é uma linguagem capaz de recolher o não visto, o não dito, [...] a literatura faz girar os saberes, não fixa, não fetichiza nenhum deles; ela lhes dá um lugar indireto, e esse indireto é precioso. Por um lado, ele permite designar saberes possíveis- insuspeitos, irrealizados: a literatura trabalha nos interstícios da ciência (Barthes, 1977, p. 18).

Exatamente por isso que a literatura, como 'leitora' privilegiada dos múltiplos aspectos da vida de um grupo social, pode proporcionar uma construção de saberes historiográficos de grande valia, mesmo quando se trata de uma pesquisa com base numa literatura não considerada - por alguns teóricos - como literatura, ou seja, numa literatura não canônica.

Outro aspecto de relevância para a aproximação história/literatura encontra-se na construção da narrativa. É na fonte da chamada "criação estética" da literatura que a história vai poder encontrar elementos capazes de combater a aridez tão presente em sua narrativa. Como nos orienta Hayden White, "eventos históricos diferem dos eventos ficcionais", entretanto ele nos permite perceber que, assim como o literata, o historiador cria e recria discursos, e somente através de um processo de criação poética poderá fundir os eventos numa totalidade possível, construtora de uma representação. "Os fatos não falam por si mesmos, mas o historiador fala por eles, fala em nome deles, e molda os fragmentos do passado num todo cuja integridade é - na sua representação - puramente discursiva" (White, 1995, p. 137-141). 
Sabendo que a história cultural, como bem nos lembra Roger Chartier, "[...] tem por principal objetivo identificar o modo como em diferentes lugares e momentos uma determinada realidade social é construída, pensada, dada a ler" (Chartier, 1998, p. 16-17), então, para estudo e entendimento dessa história devem ser percorridos caminhos de interpelações variadas, assentados numa atitude "barroca" do pesquisador. Atitude essa que se caracteriza, sobretudo, pela multiplicidade de perspectivas, pela complexidade e pela diversidade de olhares, bem como da utilização de variadas referências e vestígios acerca do objeto em estudo.

Pensando a investigação historiográfica a partir do discurso literário, podemos seguir Eagleton quando este afirma que

[...] a história da moderna teoria literária é parte da história política ideológica de nossa época [...], a teoria literária está indissoluvelmente ligada às crenças políticas e aos valores ideológicos. Na verdade, a teoria literária é, em si mesma, menos um objetivo de investigação intelectual do que uma perspectiva na qual vemos a história de nossa época. Tal fato não deveria provocar surpresa, pois qualquer teoria relacionada com a significação, valor, linguagem, sentimento $e$ experiência humanos, inevitavelmente envolverá crenças mais amplas $e$ profundas sobre a natureza do ser $e$ da sociedade humanos, problemas de poder e sexualidade, interpretações da história passada, versões do presente e esperanças para o futuro (Eagleton, p. 268).

A literatura e a história são discursos. Como na leitura de Foucault toda forma de discurso é uma forma de disputa de poder, os discursos literários e históricos apresentam-se, em toda sociedade, como uma produção que é "[...] ao mesmo tempo controlada, selecionada, organizada $e$ redistribuída por certo número de procedimentos que tem por função conjurar seus poderes $e$ perigos, dominar seu acontecimento aleatório, esquivar sua pesada e temível materialidade" (Foucault, 1996, p. 8-9). Para Barthes,

[...] a narração dos acontecimentos passados, submetida comumente [...] à sanção da "ciência" histórica, colocado sob a "caução" imperiosa do real, justificada por princípios de exposição "racional", [...] difere realmente, por algum traço específico, por uma pertinência indubitável da narração imaginária, tal como se pode encontrar na epopeia, no romance, no drama? (Barthes, 2004, p. 163-164).

Os discursos estão sempre relacionados a interesses específicos, de grupos específicos, em momentos específicos; isto é, estão sempre relacionados a disputas de poder, o que nos conduz à afirmação de que nenhum discurso é inocente. Certamente, em quaisquer questões ligadas à teoria literária e à escrita literária as práticas culturais, políticas, sociais e econômicas estão inseridas "até os ossos". A teoria literária "pura" é uma falácia, ou seja, toda literatura, bem como toda teoria da literatura, está impregnada de ideologia, de modos de ler o mundo e não há meios para esconder ou disfarçar esse fato, mesmo que isto tenha sido pretensão de alguns teóricos ao longo dos tempos. Por conseguinte, longe de tomarmos essa discussão por encerrada, há que se lembrar 
que, substancialmente, as relações imbricadas entre os campos da literatura e da história parecem estar em contínua confluência interdisciplinar. Em suma, tais imbricações refletem, ocorrem nas inferências postuladas pelos processos discursivos postos no círculo jogado pela narrativa histórica daquilo que é narrado.

Quando tratadas sem suas particularidades tanto a literatura quanto a história se distinguem em suas afinidades e objetivos, porém, ao se analisar as diferenças teóricas e metodológicas de cada uma, é possível se perceber uma variedade de significações discursivas que devem e podem ser tomadas pelos dois campos de estudo como possibilidade de ampliação da complexidade epistemológica do contexto social.

Torna-se necessário abordar aqui, mesmo que de forma extremamente tangencial, as dificuldades que a história cultural pode apresentar ao historiador que utiliza vestígios não passíveis de comprovação, como por exemplo a literatura. Pois a capacidade de "captação" da cultura, das visões de mundo, apresentada por esse tipo de material não pode ser submetida à "prova" (Darnton, 1986). Por isso mesmo, esse outro enfoque exige da prática historiográfica um rigor cada vez maior. Como nos lembra Bourdieu (1999), devemos seguir sempre com "uma vigilância epistemológica" sistemática. O historiador não pode se olvidar que todo campo apresenta um conjunto de habitus impossíveis de serem ignorados, sob pena de perder, no caso das ciências, seu status de campo científico. A narrativa histórica descreve os acontecimentos contidos num registro "de modo a informar ao leitor o que deve ser tomado como ícone dos acontecimentos a fim de torná-los familiares a esse leitor" (White, 1995, p. 105). Nessa perspectiva, embora os historiadores possam aprender algo com as técnicas narrativas dos literatos, isso não significa que este resolverá todos os seus problemas na construção do conhecimento histórico, já que os historiadores não são livres para inventarem uma narrativa, um contexto social, pois é improvável "[...] que sejam capazes de condensar os problemas de uma época na narrativa sobre uma família, como frequentemente o fizeram os romancistas" (Burke, 1992, p. 340).

Ao se estabelecer um diálogo entre a visão de mundo apresentada por Carolina de Jesus, em seu livro Quarto de Despejo: Diário de Uma Favelada, e a do cordel Ceilândia, Cidade em Flor, de Manoel Raimundo, é imprescindível analisar sistematicamente, mas sem engessamentos epistemológicos, as práticas sociais, tão caras aos estudos da história cultural e da literatura. Práticas essas que corroboram para o engendramento da socialidade, num determinado espaço; no caso dos nossos autores, o espaço urbano.

Antes de iniciar a análise propriamente dita das referidas obras, é necessário esclarecer alguns aspectos das mesmas. O livro de Carolina Maria de Jesus é narrado em primeira pessoa, na forma de um diário com um recorte temporal - determinado por Aldário Dantas, repórter que publicou o livro de Carolina - que vai de 15 de julho de 1955 a 01 de janeiro de 1960, sendo que 
ocorre uma interrupção de aproximadamente três anos - de 1955 a 1958.

O tempo da narrativa é um tempo que repete de modo extremamente contundente, as tarefas realizadas cotidianamente, como que querendo marcar uma vida sem alternativa, sem saída. É um tempo que ao mesmo tempo em que aprisiona pela repetitividade das ações cotidianas, liberta para circularidade nos espaços, nas diferentes esferas institucionais e nãoinstitucionais: Delegacia, Igreja, ruas, Jornal e outros. O livro apresenta uma linguagem clara, forte e áspera. Carolina tem a intenção de escrever. Escrever para refletir, para escancarar os problemas da Favela, para mostrar aos políticos como vivem os pobres e principalmente, sua escrita tem um caráter de denúncia. A denúncia de uma cidade que se moderniza de forma excludente, na medida em que alguns usufruem da modernização, outros, como ela assistem a este processo, à margem.

O texto de Manoel Raimundo, escrito sob a forma de cordel, narra a mudança das invasões formadas pelos trabalhadores responsáveis pela construção de Brasília, que expurgados do espaço do Plano Piloto ou de qualquer outro espaço, foram construindo as 'favelas dos pioneiros', na periferia da Nova Capital do Brasil. Esses favelados foram posteriormente assentados em um espaço que recebeu o nome de Ceilândia. Onde inicialmente não havia nenhuma infraestrutura e as dificuldades eram de toda ordem, segundo deixa ver o texto de Manoel Raimundo.

A personagem de Carolina Maria de Jesus adota uma atitude de detetive, de observadora inteligente, que ao percorrer as ruas da cidade de São Paulo, onde cata o lixo, e ao habitar a favela, percebe e vivencia os diferentes espaços e o fazer social neles territorializado. Fazer esse, que possibilita à personagem nos apresentar um vasto universo que, mesmo sendo outro, interage com a favela num movimento de mão-dupla, onde se entrecruzam práticas sociais e culturais das camadas populares da periferia com as dos habitantes das ruas do centro.

Quarto de despejo se situa na contramão da história de modernização de São Paulo; nessa narrativa estão expostas as fraturas da cidade. A realidade degradada emerge furiosa nas pontas dos tocos de lápis, os seres abandonados e carentes são parte dos fragmentos diários que estruturam a narrativa de um eu lírico que transforma aquilo que cata em matéria de literatura. $\mathrm{A}$ busca constante de lixos reflete uma espécie de busca do sonho de Carolina: publicar seus textos e se mudar do "quarto de despejo" para a sala de visitas. Carolina, em sua escrita dura $e$ impiedosa, coloca em xeque as estruturas da sociedade; ela recolhe nas ruas da cidade de São Paulo as práticas sociais experienciadas cotidianamente no mundo, com destaque em especial para o quarto de despejo, a favela do Canindé.

No espaço da cidade, onde se insere a Favela do Canindé, circulam atores sociais portadores das mais variadas características que, a partir do ordinário, vão construindo as suas representações assentadas no imaginário e no simbólico religioso/político/social/cultural. Quarto de Despejo: Diário de Uma Favelada é um livro, escrito em forma de diário, no qual a autora tece 
uma trama que possibilita perceber com detalhes a cotidianidade da favela. De forma repetitiva $e$ minuciosa a personagem vai dia-a-dia apresentando ao leitor o universo do Canindé.

Para captar a alma desse Quarto de Despejo, ela "cata" nas ruas da favela, na fila da torneira de água e nas brigas da vizinhança, as conversas, os olhares, fatores que compõem as práticas sociais e culturais dos favelados.

Assim como tem sido feitas as análises acerca do desenvolvimento urbano na modernidade, os estudos históricos seguidores da lógica da economia capitalista, fundamentamse no mensurável e no racional, ou seja, naquilo que pode ser contabilizado. Os estudiosos ocupados com as ciências sociais e atentos em retratar as sutilezas subterrâneas do modo de vida, nem sempre constatadas pelos ditos documentos oficiais legitimados, não devem desprezar o rico material de pesquisa sócio-histórica que tanto a personagem construída por Carolina Maria de Jesus como a narrativa do cordelista Manoel Raimundo apresentam.

Cabe aqui, não uma justificativa ou um mea culpa, mas um esclarecimento e também a marcação de um posicionamento: os pesquisadores das ciências humanas e sociais não devem tratar a literatura tão somente como "fonte de pesquisa", mas como um dos muitos elementos constitutivos do fazer humano. Precisa ser pensada, também, como ato de criação, de fruição, de construção de sentidos e significados no seio das práticas discursivas. Fator que pode estabelecer uma relação, não de sobreposição, mas de ajuda mútua, de trocas permanentes, o que certamente possibilitará um diálogo bastante frutífero para ambas: história e literatura.

Seguindo os postulados do capitalismo, as cidades passam a ser idealizadas como um grande projeto arquitetônico, capaz de valorizar o racionalismo e a lógica urbanística da modernidade, sem levar em conta o fazer humano que se instaura na construção de toda ambiência urbana. Fazer humano esse percebido e destacado por Carolina, quando deixa claro em seu livro, por exemplo, a sua vontade de sair da favela, pois para ela a falta de solidariedade, a implicância das vizinhas com os filhos, o alcoolismo, as constantes brigas, as palavras de baixo calão, tudo isso transformava o lugar no "inferno".

É possivel notar, no transcorrer de seu diário, que a favela é colocada como sendo um espaço que constrói e é construído pelos atores sociais que nela habitam. Dessa forma produz o tecido social urbano que tanto em Carolina como em Manoel Raimundo encontra-se revestido e perpassado de desordem, imperfeição, confusão, mas também de afetos e paixões.

Esses pluralismos, imbricados nas relações humanas, são evidências da não homogeneidade da vida cotidiana. Tais pluralismos, contrapontos da unicidade prevalente nas ciências humanas durante a modernidade, apresentam-se como aspectos de sintonia entre Carolina e Manoel Raimundo, na abordagem realizada por ambos acerca do mundo urbano. 
Apesar das concordâncias entre os dois, existem também as diferenças na forma de vivenciar o espaço em que habitam. Enquanto Carolina quer sair daquele lugar - "Oh! Se eu pudesse mudar daqui para um núcleo mais decente" (Jesus, 2001, p. 9), pois:

As vezes mudam algumas famílias para a favela, com crianças. No início são educadas, amáveis. Dias depois usam o calão são soezes e repugnantes. São diamantes que transformam em chumbo. Transformam-se em objetos que estavam na sala de visitas e foram para o quarto de despejo (Jesus, 2001, p. 39. [...] meu desejo era andar bem limpinha, usar roupas de alto preço, residir numa casa confortável, mas não é possível (p. 19).

Sonhei que eu residia numa casa resilível, tinha banheiro, cozinha, copa e até quarto de criada. Eu ia festejar o aniversário da minha filha, Vera Eunice. Senteime na mesa para comer. A toalha era alva ao lírio. Eu comia bife, pão com manteiga, batata frita e salada. Quando fui pegar outro bife despertei. Que realidade amarga! Eu não residia na cidade. Estava na favela. Na lama às margens do Tietê (p. 35).

A favela, considerada pela autora como o lugar da degradação dos que nela habitam só permite ao sujeito vivenciar a fome e experienciar uma condição social marginalizada, ela embrutece o humano.

Já Raimundo tem esperanças de que Ceilândia, apesar dos problemas de falta de urbanização, "com a ajuda de Deus" se torne um bom lugar para se viver. Para ele, "Ceilândia a caçula de Brasília, [...] vai se tornar um lindo jardim em flor”3.

A chamada ambiência, ou seja, a atmosfera do ambiente é esse algo nebuloso e não palpável, que apresenta sua essência própria, única e não idêntica, que dá sentido aos diversos elementos unindo-os, mas respeitando as suas diversidades. Os elementos contraditórios não são superados, mas mantidos como tais. São, apesar de heterogêneos, formadores de um conjunto no qual aparecerão às diversas particularidades individuais. Não existe privilégio do objetivo sobre o subjetivo ou vice-versa, não há privilégio de nenhum dos elementos sobre os demais. Tudo aquilo que determina as atitudes individuais é importante: os modos de vida, as maneiras de pensar, as inter-relações econômicas, políticas, ideológicas e religiosas, pois são esses os elementos, que no conjunto vão possibilitar a construção da vida em sociedade ${ }^{4}$, inclusive a fome.

Que efeito surpreendente faz a comida no nosso organismo! Eu que antes de comer via o céu, as árvores, as aves, tudo amarelo, depois que comi, tudo normalizou-se aos meus olhos. [...] A comida no estômago é como o combustível nas maquinas. Passei a trabalhar mais depressa. O meu corpo deixou de pesar. Comecei a andar mais depressa. Eu tinha impressão que eu deslizava no espaço. Comecei a sorrir como se estivesse presenciando um lindo espetáculo. E haverá espetáculo mais lindo do que ter o que comer? Parece que eu estava comendo pela primeira vez na minha vida" (Jesus, 2001, p. 45-46).

16 de maio. Eu amanheci nervosa. Porque eu queria ficar em casa, mas eu não tinha nada para comer. [...] Eu quando estou com fome quero matar o Janio, quero enforcar o Adhemar e queimar o Juscelino. As dificuldades corta o afeto do povo pelos políticos (JESUS, 2001, 33). 
Os nomes citados por Carolina referem-se a políticos que atuaram entre 1950 e início de 1960; esses políticos, segundo Jesus (2007), que não se lembram de pessoas como ela, que vivem nos quartos de despejo. Na sua condição de miséria, o eu lírico expõe uma ambiência como o resultado da combinação do fazer humano, gerador da transformação da natureza - fenômeno visível aos olhos - mas que vai além da ação técnica do homem. Existe também, uma "dimensão oculta”, invisível, onde, segundo Edmilson Martins (1996, 55-78), se processam todas as relações humanas, onde a cultura urbana toma forma, sendo construído pelas experiências, pelos pensamentos, pelo cotidiano urbano, solo no qual as coisas adquirem sentidos e significados. É o invisível enraizado no visível, fincado no espaço físico, no caso de Carolina, na favela.

Neste ponto é preciso esclarecer que a favela faz parte do mundo urbano. Sendo que, de acordo com Carolina, enquanto "a cidade é a sala de visitas, a favela é o quarto de despejo".

As oito e meia da noite eu já estava na favela respirando o odor dos excrementos que mescla com o barro podre. Quando estou na cidade tenho a impressão que estou na sala de visita com seus lustres de cristais, seus tapetes de viludos, almofadas de sitim. E quando estou na favela tenha a impressão que sou um objeto fora do uso, digno de estar num quarto de despejo [...] Eu classifico São Paulo assim: O Palácio, é a sala de visita. A Prefeitura é a sala de jantar e a cidade é o jardim. E a favela é o quintal onde jogam os lixos (Jesus, 2001, p. 32).

Analogia que cria uma representação da favela como sendo o espaço de despejo dos restos da cidade. Dos restos materiais, o lixo que ironicamente (ou cruelmente) sustenta a vida do favelado e dos restos humanos; para Carolina, o favelado de modo geral, é um sem caráter, um subproduto expurgado da abundância da cidade.

Já para Manoel Raimundo é diferente, pois Ceilândia ganha o status de cidade em processo de nascimento. Não é considerada como favela, mas como a cidade satélite mais nova de Brasília. Essa representação pode ser observada quando ele afirma:

\section{Ceilândia é boa cidade Lugar de muita garoa Não existe inimizade Pois só mora gente boa Aqui não a necessidade De se criar gente atoa ${ }^{5}$.}

A cidade deve ser percebida não apenas como um espaço onde se reúne um conglomerado de pessoas, mas, sobretudo como lugar de intensas e variadas trocas, tanto do indivíduo quanto da coletividade. 
Referindo-se ao mundo urbano, "Ceilândia, Cidade em Flor" faz uma abordagem acerca desse caráter de relações multifacetadas aí presentificadas, onde o espaço, bem como as relações humanas, são vistas de modo idealizado:

\author{
A cidade é uma só \\ Não há distinção de cor \\ Preto, branco e fogoió \\ Todos têm o seu valor \\ Ceilândia vai se tornar \\ Um lindo jardim em flor ${ }^{6}$.
}

Segundo Carolina, o espaço da favela mostra bem essa relação do material com o nãomaterial:

[...] a briga diária pela água, a falta de solidariedade de quem mora na favela [...] Os favelados são uns corvos. Assustei quando ouvi meus filhos gritar. Conheci a voz de Vera. Vim ver o que havia. Era Joãozinho, filho da Deolinda, que estava com um chicote na mão e atirando pedra nas crianças. Corri e arrebatei-lhe o chicote das mãos. Senti o cheiro de álcool. Pensei: ele está bêbado porque ele nunca fez isto. Um menino de nove anos. O padrasto bebe, a mãe bebe e a avó bebe. E ele é quem vai comprar pinga. E vem bebendo pelo caminho. Quando chega, a mãe pergunta admirada: - Só isto? Como os negociantes são ladrões! (Jesus, 2001, p. 109).

Segundo a personagem, todos esses fatores tornam a favela um lugar, um espaço pouco ou nada apropriado para se viver, especialmente para "os filhos". Essa constatação é uma maneira de reafirmar como o espaço urbano se configura em uma mescla de significações e de sentidos, que lhe são atribuídos pelos atores sociais que o habitam.

Esse mosaico do modo de vida urbano, constituído pelos pequenos acontecimentos e pela banalidade da vida cotidiana, imbricado de relações afetivas territorializadas, forma o substrato social que compõe a comunidade e, que se encontra potencializado na maneira pela qual é construída a polifonia dos sujeitos sociais, nos subgrupos, das grandes cidades; isto é, a maneira como essas muitas vozes se entrecruzam, no e com o espaço urbano, criando a atmosfera desse espaço.

Quando eu vou na cidade tenho a impressão que estou no paraíso. Acho sublime ver aquelas mulheres e crianças tão bem vestidas. Tão diferentes da favela. As casas com seus vasos de flores e cores variadas. Aquelas paisagens há de encantar os olhos dos visitantes de São Paulo, que ignoram que a cidade mais afamada da América do Sul está enferma. Com as suas ulceras. As favelas (Jesus, 2001, p. 85).

Simmel (1976) observa que a cidade da era da modernidade é o locus da precisão racional, da pontualidade, do relógio, da calculabilidade e do anonimato; entretanto para Maffesoli (1984; 
1996) é também a sede da sociabilidade e da socialidade, onde se pode morar, trabalhar, divertirse, perambular, em um espaço demarcado pela liberdade, pela criatividade e principalmente pela ação gregária, cimento de toda socialidade.

De acordo com as suas análises, a socialidade possui uma dimensão temporal e espacial que não pode ser negada, nem tão pouco subestimada. É certamente, em um determinado lugar que se sedimentam, com toda intensidade, os laços afetivos, o prazer, as tensões, os medos, as paixões, bem como os conflitos. No caso de Quarto de despejo este lugar é a cidade de São Paulo, que na barbárie cotidiana da metrópole produz uma sociedade marginalizada, em que o eu lírico vem a ser a porta-voz de um povo calado, que vivem à margem.

É no espaço local, seja ele o bar, a rua, a casa ou o barraco, a igreja, o lugar de reunião, o local de trabalho e/ou de lazer que as relações da vida em comunidade se concretizam, tomam forma na proximidade com o outro. As relações de socialidade estabelecidas em cada um desses espaços apresentam características específicas e possuem particularidades marcantes. Notadamente, a forma como um indivíduo ou grupo social se insere nos diferentes espaços urbanos não é homogênea. A respeito dos diversos espaços urbanos e o modo como às pessoas interagem neles, é importante observar que apresentam um quadro próprio resultante dos anseios, das estratégias e das múltiplas práticas cotidianamente engendradas pelos atores sociais que efetivamente os constroem e por eles são construídos. Vista sob esse prisma, a cidade apresentase como sendo formada por diversas ambiências onde os seus habitantes compartilham no dia-adia o prazer e ou o conflito do estar junto.

Essa relação espaço urbano/socialidade pode ser constantemente observada no mito fundador que sedimenta a sociedade ocidental que é no "torrão" e, mais precisamente, em um determinado espaço geograficamente demarcado onde os sonhos adquirem forma, tomam consistência, tornando-se passíveis de serem realizados ou não. Essa valorização do endereço, a vontade de ter a casa própria, a necessidade de ter um lugar onde se fixar, está presente no Cordel de Manoel Raimundo quando ele diz que

\footnotetext{
O povo vivia amontoado Precisavam espalhar

Pra viver mais sossegado Cada um em seu lugar Pra criar seus filhos amado Precisava ter um lar?.
}

É no barraco, na casa, nas ruas, no quarto de despejo que nascem e morrem as esperanças; que nascem as ilusões e faz brotar as desilusões; que enraíza a fome, o alcoolismo, as brigas conjugais, a luta pela água e por um pouco de sossego; que se cata a felicidade e leva para outro lugar ou que a carrega para cá. 
A cidade, através da torneira; dos chafarizes; da igreja; das praças; das ruas do centro; da periferia ou daquilo que é visível, interconectado com o invisível, ou seja, com os laços de afetividade, permite conhecer e entender as suas ambiências multifacetadas. A ligação do individuo ou grupo ao território encontra-se perpassada pelas mais diferentes práticas da vida cotidiana, pelas memórias individuais e coletivas e também pelo imaginário.

Em Ceilândia, Cidade em Flor, as lembranças do passado, tanto o vivido em outros lugares quanto o vivido em Ceilândia, remetem a uma época mais difícil, onde havia mais sofrimento, mais medo e mais violência. Dificuldades essas que no tempo presente estão representadas de forma amenizadas e revestidas por uma densa camada de esperança de uma vida melhor, pois segundo ele,

\section{Em Ceilândia é diferente \\ Porque não é invasão \\ A polícia é competente $\mathrm{Na}$ sua execução \\ No cumprimento da lei \\ Prende assasino e ladrão.}

\author{
O povo corria nas ruas \\ Que inchava os mocotó \\ A cantiga da perua \\ É de pior a pior \\ A vida aqui foi bem crua \\ Porém hoje esta melhor'.
}

Os atores sociais apropriam-se dos espaços urbanos estabelecendo o enraizamento daquilo que é o substrato de toda a vida comunitária: o "estar-junto", o compartilhar territorializado tanto dos pequenos quanto dos grandes acontecimentos, tanto das coisas alegres quanto das coisas tristes. Em Carolina mais coisas tristes do que alegres, mais angústia do que felicidade, mais fome do que comida, mais lixo do que luxo.

O homem é uma mistura de Apolo e Dioniso. É em Apolo deus da luz, da razão e do sol, que busca sustentáculo para firmar a sua racionalidade e, em Dioniso, deus das festas, do vinho, da subjetividade, da emoção e do exagero, onde bebe na fonte que lhe sacia a necessidade do afetivo. É nessa representação construída desde a Grécia Antiga - suspensa pelo pensamento dicotomizante propagado pelo Positivismo - que tentamos encontrar a fundamentação para outra vez construirmos o entrelaçamento do emocional com o racional.

O ambiente urbano, concebido como sendo sedimento da interação entre subjetividade e racionalidade, torna-se o resultado de uma construção coletiva, marcado pela potencialização dessa dualidade que caracteriza o ser humano. A configuração do ambiente urbano ultrapassa a dimensão somente do racional, visto que se apresenta como um espaço perpassado pelas experiências vividas no dia-a-dia, no cotidiano, no fazer diário. Em Quarto de Despejo: Diário de Uma Favelada, Carolina faz essa constatação referindo-se ao cotidiano dos moradores da Favela do Canindé.

Carolina percorre as ruas de São Paulo onde cata o lixo para negociar e "cata" as diferenças para se posicionar, enquanto "sujeito social", dentro da Favela do Canindé assumindo- 
se como sendo portadora de múltiplas identidades e de diferenças significativas em relação aos seus vizinhos. Manoel Raimundo também percorre as ruas do Bandeirante, empurrando um carro pesado, onde negocia bananas e 'cata' os fragmentos de lembranças desde sua chegada em Brasília, "em maio de 68", até sua mudança para Ceilândia; nesse "catar" diário é que ele também vai construindo as suas representações.

Carolina, apesar de não ter o capital econômico necessário para satisfazer as suas necessidades materiais básicas e a dos filhos, detém um capital cultural que lhe concede um grande poder de interferência dentro da favela. Em sua obra, o escrever e o ler aparecem como traço de distinção, da diferença que a distingue dos demais moradores da Favela do Canindé. Além da escrita e da leitura existem, segundo Carolina, outras marcas que a diferencia dos demais, especialmente das outras mulheres.

A partir de uma sequência alegórica de imagens fornecidas através dos diferentes tipos de trabalhos informais exercidos por Carolina, a personagem mostra como o seu trânsito pelos diferentes espaços onde 'cata' tudo - material e não-material - como sendo um fator importante da construção de sua(s) identidade(s).

As identidades urbanas pensadas de modo homogeneizado subordinam quaisquer formas de diferenças e por isso mesmo devem ser contestadas. Os atores sociais encenam diferentes papéis nos microcosmos sociais pelos quais transitam; procuram manter uma identificação mesmo que efêmera, dentro do conjunto maior da sociedade. Como não estão livres do jogo de poder, de divisões e contradições internas, os indivíduos sentem necessidade de pertencer a um grupo em busca da expressão de seus sentimentos.

Neste ponto da análise é importante ressaltar que os textos de Carolina e de Manoel Raimundo são obras de criação literária, de fruição; entretanto, não apresentam uma linguagem erudita. Os textos, tanto um quanto o outro, configuram-se em leituras do social, do político, do econômico, que são perpassadas e ao mesmo tempo perpassam o cultural, tendo como tônica um relato que faz saltar aos olhos do leitor a tensão social que caracteriza as relações sociais na modernidade urbana, especialmente no subgrupo favela.

Na medida em que Carolina se coloca como catadora de coisas e de informações, ela adentra os diversos microcosmos sociais, faz eco com as vozes dos atores sociais que transitam no espaço da favela e da cidade, o que possibilita o desfile em sua escrita dos rumores das brigas de vizinhos, da omissão do Estado, da especulação imobiliária, da inserção da Igreja, do desemprego, da miséria que permeiam as ruas $\mathrm{A}, \mathrm{B}, \mathrm{C}$..., e também deixa entrever a fábrica, as ruas do centro, o modo como eram vistos os nortistas, os portugueses, os negros, os ciganos, compondo assim um quadro representativo da vida urbana da favela do Canindé e da cidade de São Paulo, no período de 1955 a 1958. 
A escrita de Manoel Raimundo e Carolina apresenta aspectos convergentes na medida em que, tanto para um quanto para o outro, o coletivo corporifica no espaço expectativas, frustrações, medos, ressentimentos, sensações de estranhamento e de encantamento, fatores que promovem a criação da ambiência urbana.

Carolina Maria de Jesus, no decorrer do seu trabalho, apresenta a história do homem e da mulher comum. Não daqueles aclamados pelos jornais, mas de uma mulher que se enche de esperança, que é tomada pela descrença, mas que luta no dia-a-dia para vencer suas dificuldades. Uma mulher comum capaz de olhar para o céu e ver a poesia presente na chegada do "astro-rei" e no chiar da gordura na panela, representantes de grande espetáculo, motivos de alegria. Ou que presentifica na chuva as suas tristezas, a sua fome e a dos filhos e de mais desalento. Vale observar que o modus de viver a miséria, ora apresentado, descortina-se de modo ambíguo, pois ambíguo também, é o ser e o fazer humano. Às vezes mostra-se prenhe de poesia e aventura, outras, descrente de viver uma vida onde estão sempre em cena os espetáculos hediondos, nojentos e carregados de violência, que cansam, entristecem, fazem chorar e não merecem aplausos.

Essa escolha de forma de escrita permite a configuração de uma temporalidade no qual ao se construir uma representação do passado que convence como tal. $\mathrm{O}$ arranjo do texto organiza as informações a serem apresentadas, a partir de uma aparência fragmentada, onde as informações se diluem nos múltiplos discursos. São essas visões múltiplas que expõem temas reais da história do cotidiano dessa gente miúda, pois criam uma leitura heterogênea, ambígua, que abre espaço para reflexões no campo da história, na medida em que as personagens Carolina, assim como os versos de Manoel Raimundo, procedem a uma crítica contundente à moral capitalista e mostram como o ser humano desenvolve estratégias visando criar alternativas outras que proporcionem a sobrevivência no meio urbano. As práticas urbanas de meados do século XX encontram-se evidenciadas e vivenciadas com desenvoltura em Quarto de Despejo: Diário de uma Favelada e em Ceilândia, Cidade em Flor.

\section{Considerações finais}

O caráter das relações sociais urbanas vem apresentando significativas transformações, especialmente em relação às identidades, à temporalidade e à construção dos espaços. $\mathrm{Na}$ contemporaneidade, longe de se buscar a fantasmagoria dos deuses e heróis ou a futura vida no paraíso, descrente do futurismo tão decantado no início da modernidade, busca-se como pode ser lido em Carolina Maria de Jesus, a satisfação das necessidades imediatas do indivíduo, tanto das materiais quanto das emocionais. Isto porque as promessas da modernidade não foram cumpridas; promessas de uma vida melhor, de acesso de bens materiais para todos, de realização dos desejos 
de consumo e felicidade foram tornando-se cada vez mais distantes, principalmente para os subgrupos das periferias urbanas.

Nesse sentido, lembramos Edgar Morim (2001) quando este chama atenção para o farto de que os homens e mulheres que vivenciaram os séculos anteriores pautaram suas ações na crença de um futuro, fosse este "repetitivo ou progressivo". Enquanto isto, "o século XX descobriu a perda do futuro, ou seja, sua imprevisibilidade [...] a história humana foi e continua a ser uma aventura desconhecida, o futuro permanece aberto e imprevisível” (Morin, 2001, p. 79).

Essa percepção da incerteza histórica e do descrédito no mito prometeico leva a uma outra postura do indivíduo dentro do mundo urbano: a busca das satisfações imediatas, relacionamentos efêmeros e desprezo pelo que não pode ser desfrutado agora. A ordem, a razão e a uniformização codificadoras e também identificadoras da vida na cidade moderna produziram, em alguns aspectos, a perda de sentido da vida. Em alguns momentos do livro, Carolina sente-se como se tivesse chegado ao "fundo do poço", lugar onde não mais existe prazer, nem vontade de viver a vida, nem tampouco de construir projetos para o futuro.

Entretanto, em "Ceilândia Cidade em Flor", apesar de todas essas desventuras, há uma grande vontade de mudança, muita fé e muita esperança na possibilidade de caminhar em busca de um futuro, uma outra vida: mais digna, sem violência e especialmente com muita poesia, trovas e versos.

Frente ao racionalismo da sociedade moderna que se firma como perfeitamente capaz de satisfazer as necessidades de consumo do individuo, encontra-se expressa em Quarto de Despejo: Diário de Uma Favelada e em Ceilândia, Cidade em flor uma outra verdade. A verdade dos despossuídos, daqueles que têm fome, daqueles que buscam um canto para morar, daqueles que andam descalços, daqueles que precisam correr atrás das 'peruas' ou levantar de madrugada para enfrentar uma fila em busca de água, daqueles que vivem do trabalho informal, daqueles que vivem dos restos do lixo e, sobretudo daqueles que precisam de mais força e coragem para lutar pela vida.

A cidade para estes autores não é apenas uma reflexão sobre a realidade política, mas é, também, uma cidade de conteúdo e forma, onde as vozes dos seus moradores desconstroem a cidade sem problemas, e fazem emergir, por meio de múltiplos recursos linguísticos, a cidade vivenciada cotidianamente, ora repleta de esperança como a terra prometida, ora como um lugar de desalento que não acolhe nenhuma promessa de melhoria de vida para os que nela habitam.

Através de "frestas" da realidade, os acontecimentos vividos, as memórias e registros visuais que compõem as duas narrativas, permitem aos autores se lançarem em temas profundos que refletem a experiência humana, uma característica da produção literária. A pesquisa histórica e a habilidade da escrita de Carolina de Jesus e Manuel Raimundo acabam por conectar o universo 
fictício de suas narrativas às possibilidades do registro histórico, discutindo aspectos tangíveis como

o desenvolvimento econômico da cidade e a vida social, reconstruídos através de pesquisa histórica em comunhão com a arte de narrar via literatura.

\section{Referências}

BARTHES, Roland. Aula. Aula inaugural da cadeira de semiologia literária do Colégio de França. 9 ed. São Paulo: Cultrix, 1977.

BARTHES, Roland. O rumor da lingua. Trad. Mario Laranjeira. 2 ed. São Paulo: Martins Fontes, 2004.

BOURDIEU, Pierre. O poder simbólico. Lisboa: Editora Difel, 1999.

BURKE, Peter. A escrita da História: Novas Perspectivas. São Paulo. Editora UNESP, 1992.

CHARTIER, Roger. A História Cultural: entre práticas e representações. Lisboa: Editora Difel, 1998.

DARNTON, Robert. O grande massacre de gatos. Rio: Graal, 1986.

EAGLETON, Terry. Teoria da Literatura: uma introdução. Tradução: Waltensir Dutra. 4 ed. São Paulo: Martins Fontes, 2001.

FISCHER, Ernest. A necessidade da arte. Tradução de Leandro Konder. Editora Zahar Editores S.A. Rio de Janeiro, 1983.

FOUCAULT, M. A ordem do discurso. São Paulo: Loyola, 1996.

JESUS, Carolina Maria de. Quarto de despejo: diário de uma favelada. 10 ed. São Paulo: Francisco Alves, 2001.

MAFFESOLI, Michel. A conquista do presente. Rio de Janeiro: Rocco, 1984.

MAFFESOLI, Michel. No fundo das aparências. Petrópolis: Vozes, 1996.

MORIN, Edgar. Os sete saberes necessários à educaşão do futuro. 4 ed. São Paulo: Cortez; Brasília, D.F., UNESCO, 2001.

SIMMEL, Georg. O fenômeno urbano. Rio de Janeiro: Zahar editores, 1976.

WHITE, Hayden: Meta-história: A imaginação histórica do século XIX. Tradução de José Laurênio de Melo. São Paulo: Editora da Universidade de São Paulo, 1995. 


\section{Fontes}

JESUS, Carolina Maria de. Quarto de despejo: diário de uma favelada. 10 ed. São Paulo: Francisco Alves, 2001.

RAIMUNDO, Manoel. Ceilândia, Cidade em flor (cordel exemplar em folheto do autor).

\footnotetext{
${ }^{1}$ Sensibilidade barroca se constitui como sinônimo de uma postura do pesquisador diante do seu objeto de pesquisa. Segundo Maffesoli o pesquisador deve rodopiar em torno do seu objeto de estudo, procurando sempre a análise que possibilite a heteroglossia bem como a polifonia, ou seja, quebra com a ideia de interpretação una, tempo linear, objetividade absoluta e racionalismos exacerbados, defendidos pela história tradicional.

${ }^{2}$ Os termos habitus e campus são aqui utilizado no sentido que o sociólogo francês Bourdieu lhes atribui. O primeiro é um conjunto de formas de classificar, de ver o mundo e formas de agir que fazem parte de um campo social e que, apesar de serem social e culturalmente construídos, à medida em que são incorporadas pelos participantes de um determinado campo, tendem a ser consideradas naturais. O segundo, são as "estruturas estruturantes" do habitus. Existe uma relação íntima entre campus e habitus.

${ }^{3}$ RAIMUNDO, Manoel. Ceilândia, Cidade em Flor (cordel exemplar em folheto do autor).

${ }^{4}$ Maffesoli, no decorrer de seus estudos, estabelece uma distinção entre sociabilidade (referente a aspectos jurídicos das relações) e socialidade (ligado ao afetual, ao emocional).

${ }^{5}$ RAIMUNDO, exemplar do autor.

${ }^{6}$ RAIMUNDO, exemplar do autor.

${ }^{7}$ RAIMUNDO, exemplar do autor.

${ }^{8}$ RAIMUNDO, exemplar do autor.
} 